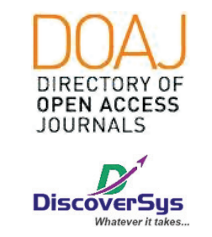

Published by DiscoverSys

\section{Risk factors of preeclampsia and eclampsia in Sanglah General Hospital from March 2016 to March 2017}

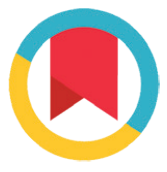

CrossMark

\author{
Ng Teng Fung Vincent, ${ }^{1 *}$ I Made Darmayasa, ${ }^{2}$ Anom Suardika ${ }^{2}$
}

\section{ABSTRACT}

Background: Preeclampsia and eclampsia have been increasing at an alarming rate. It is a challenging task for doctors and pregnant mothers. Preeclampsia defined as new onset of hypertension ( $\geq 140 \mathrm{mmHg}$ systolic or $\geq 90 \mathrm{~mm} \mathrm{Hg}$ diastolic on at least two occasions 6 hours apart) and proteinuria (at least $1+$ on dipstick or $\geq 300 \mathrm{mg}$ in a 24-hour urine collection) after 20 weeks of gestation. Eclampsia defined as neurologic involvement in the form of generalized tonicclonic convulsions in women with preeclampsia is termed eclampsia if the seizures cannot be attributed to any other cause such as epilepsy, cerebral infection, tumor or ruptured aneurysm.

Aim: This study aims to find the association of risk factors for preeclampsia and eclampsia. The risk factors for preeclampsia and eclampsia are obesity, primigravida, multiple pregnancies, diabetes, pre-existing hypertension, family history, expecting mother's age, nutritional status, and socioeconomic status. The study was carried out by using descriptive research and data were collected from medical records in Sanglah hospital which has 140 cases.

Results: The results for preeclampsia are highest in expecting the age of 20-35 years old, primigravida women with gestational age $>37$ weeks, overweight and overnourished women, a middle socioeconomic status and also without risk factors. The results for eclampsia are dominant in expecting age of 20-35 years old, primigravida women with gestational age $>37$ weeks, women with middle socioeconomic status and majority without risk factors, and women who are overweight and overnourished.

Conclusion: Preeclampsia and eclampsia cases are highest in expecting age of 20-35 years old, primigravida women with gestational age $>37$ weeks, overweight and overnourished women, majority women without risk factors and from middle socioeconomic status.
${ }^{1}$ Bachelor of Medical Program, Faculty of Medicine, Udayana University

${ }^{2}$ Department of Obstetrics and Gynecology, Sanglah General Hospital, Faculty of Medicine, Udayana University
*Correspondence to: $\mathrm{Ng}$ Teng Fung Vincent, Bachelor of Medical Program, Faculty of Medicine, Udayana University vinngtf@gmail.com

Keywords: preeclampsia, eclampsia, obstetrics emergency

Cite This Article: Vincent, N.T.F., Darmayasa, I.M., Suardika, A. 2018. Risk factors of preeclampsia and eclampsia in Sanglah General Hospital from March 2016 to March 2017. Intisari Sains Medis 9(2): 131-136. D0I: 10.1556/ism.v9i2.162

\section{INTRODUCTION}

Preeclampsia has been increasing at an alarming rate worldwide. It is a challenging tasks for doctors and pregnant mothers. Even though medical field is advancing, the etiology and mechanism of preeclampsia is still unknown. There has been risk factors associated with preeclampsia and eclampsia such as obesity, primigravida, diabetes and etc. Preeclampsia is a systemic syndrome that is typically characterised by new onset of hypertension ( $\geq 140 \mathrm{mmHg}$ systolic or $\geq 90 \mathrm{~mm} \mathrm{Hg}$ diastolic on at least two occasions 6 hours apart) and proteinuria (at least $1+$ on dipstick or $\geq 300 \mathrm{mg}$ in a 24 hour urine collection) after 20 weeks of gestation. Eclampsia is a rare condition but can cause serious complication for pregnant mother and fetus. Eclampsia can be defined as neurologic involvement in the form of generalised tonic-clonic convulsions in women with preeclampsia is termed eclampsia if the seizures cannot be attributed to any other cause such as epilepsy, cerebral infection, tumour or ruptured aneurysm. ${ }^{1}$

The incidence of preeclampsia is estimated to $3 \%-10 \%$ of all pregnancies. Preeclampsia is a major cause of maternal mortality which accounts for $15-20 \%$ in developed countries and morbidities, perinatal deaths, preterm birth, and intrauterine growth restriction. It is estimated 1 in 20 pregnancies. From the data of journal "Epidemiology and risk factors of preeclampsia; an overview of observational studies", preeclampsia will develop into eclampsia which accounts for $10 \%$ of maternal death. An estimated 50,000 women worldwide die annually from preeclampsia. The incidence of preeclampsia was reported $2.8 \%$ from a study in Israel, 5.8\% reported from Scotland, $14.1 \%$ reported from Australia and 5\% reported from Seattle. ${ }^{2}$ In Indonesia, the cases of severe preeclampsia and eclampsia account for 1.5-25\% of maternal death. For neonatal death, the data is $45-50 \% .^{3}$ In 2012 the maternal mortality rate is 259 death in 100.000 birth and $0.4-7.2 \%$ is caused by preeclampsia. Without proper management, preeclampsia can cause serious complication. ${ }^{4}$ Despites the advance of medical filed, so far the only known cure for preeclampsia is delivery. ${ }^{5}$ 
There is some controversial for the theory of preeclampsia. One of the example is study on vitamin D. From the result of "Longitudinal vitamin D status in pregnancy and the risk of pre-eclampsia", it shows there is a relationship of vitamin $\mathrm{D}$ to the risk of preeclampsia. ${ }^{6}$ However, some studies shows that the increase of risk to preeclampsia has no relation to vitamin $\mathrm{D}^{7,8}$ In addition, as all of us know uterine spiral arteries is important for supplying nutrient. This theory of spiral arteries remodeling also under controversial. A study from "Controversies on Preeclampsia through the lens of Reproductive Immunology: A Systematic Review" states that leukocytes such as natural killer cells and etc. are important in the remodelling of spiral arteries. In contrary, a study states that the present of leucocytes might be involved in endothelial dysfunction. ${ }^{9}$ Other than that, the use of low aspirin to prevent preeclampsia has been use worldwide but it also remains controversial. A study from "Prevention of pre-eclampsia with low-dose aspirin or vitamins $\mathrm{C}$ and $\mathrm{E}$ in women at high or low risk: a systematic review with meta-analysis" states that there is no effect of aspirin to prevent preeclampsia. ${ }^{10}$ In contrast, a study from "Prevention of preeclampsia and intrauterine growth restriction with aspirin started in early pregnancy: a meta-analysis" shows a different result. ${ }^{11}$

From this research, researcher interested to study the risk factors of preeclampsia and eclampsia and use it to assess preeclampsia and eclampsia. Furthermore, by doing this research a suitable surveillance plan can carry out to prevent preeclampsia and eclampsia from happening to pregnant women which improve their quality of life. This research also can improve knowledge and help doctors to detect early signs of preeclampsia and eclampsia.

\section{METHODS}

This research is a descriptive observational study with the cross-sectional study approach to identify the risk factors of preeclampsia and eclampsia. The subject of this study is preeclampsia, and eclampsia patients get from medical records in Emergency Unit and Polyclinic in Sanglah hospital in Denpasar, Bali. The target population of this study is preeclampsia and eclampsia pregnant women who visited or admitted to Emergency Unit and Polyclinic in Sanglah hospital from March 2016 until March 2017. This research is conducted using secondary data, namely the medical record data attained from Sanglah General Hospital. The medical record data which meet the criteria are included in the research sample, afterward coding, data tabulation and data entry into the computer are conducted. Data is also displayed in the form of a table. Data analysis comprises of descriptive analysis which is conducted to explain the characteristics of each variable.

\section{RESULTS}

Expecting mother's age with preeclampsia and eclampsia is categorized into 3 groups which are less than 20 years old, 20 to 35 years old and more than 35 years old. As shown in table 1, the number of the age group of $<20$ years old is 10 persons $(7.8 \%)$. The number of the age group of 20 to 35 years old is 84 persons $(65.6 \%)$ and the group of $>35$ years old has 34 persons $(26.6 \%)$. We can conclude that preeclampsia patients are higher in 20-35 years old with a proportion of $65.6 \%$. From the data, it also shows that eclampsia with age 20-35 years old is the most with 10 cases compared to $>35$ years old which only 2 cases.

As shown in table 2, it shows that the total number of preeclampsia patients with primigravida is 51 persons. From there, the gestational age $<37$ weeks has 25 persons whereas the gestational age $\geq 37$ weeks has 26 persons. The number of preeclampsia patients with secundigravida and $<37$ weeks is 12 persons while there is 19 persons in preeclampsia patients with secundigravida and $\geq 37$ weeks which it presents a total of 31 persons in secundigravida. Patients with multigravida have a total of 46 persons, the number of gestational age $\geq 37$ weeks is 20 persons and gestational age $<37$ weeks has 26 persons. Based on the data collected, we can conclude that most patients with preeclampsia are primigravida. From the eclampsia data, it also shows that age 20-35 years old is the most with 10 cases compared to $>35$ years old which only 2 cases. Furthermore, there are 6 cases for primigravida, 2 cases of secundigravida and 4 cases of multigravida. The gestational age of the pregnant mother when admitted to hospital is higher for $\geq 37$ weeks compare to $<37$ weeks which are 7 cases and 5 cases respectively.

\section{Table 1 Characteristic of Expecting Age}

\begin{tabular}{lcc}
\hline $\begin{array}{l}\text { Expecting Age } \\
\text { Category }\end{array}$ & Frequency & Percentage \\
\hline $\begin{array}{l}\text { Preeclampsia }(\mathbf{n}=128) \\
\quad<20 \text { years old }\end{array}$ & 10 & $7.8 \%$ \\
$20-35$ years old & 83 & $65.6 \%$ \\
$\quad>35$ years old & 34 & $26.6 \%$ \\
Eclampsia $(\mathbf{n}=12)$ & & \\
$20-35$ years old & 10 & $83.4 \%$ \\
$>35$ years old & 2 & $16.6 \%$ \\
\hline
\end{tabular}


Table 2 Distribution of Gravida and Gestational Age in Preeclampsia and Eclampsia

\begin{tabular}{lcc}
\hline Characteristic & Total & Percentage \\
\hline Preeclampsia $(\mathbf{n}=\mathbf{1 2 8})$ & & \\
Gravida & 51 & $39.8 \%$ \\
$\quad$ Primigravida & 31 & $24.2 \%$ \\
$\quad$ Secundigravida & 46 & $35.9 \%$ \\
$\quad$ Multigravida & & \\
Gestational age & 63 & $49.2 \%$ \\
$\quad<37$ weeks & 65 & $50.8 \%$ \\
$\quad>37$ weeks & & \\
Eclampsia $(\mathbf{n}=\mathbf{1 2})$ & & $33.4 \%$ \\
Gravida & 6 & $50 \%$ \\
Primigravida & 2 & $16.6 \%$ \\
Secundigravida & 4 & $33.4 \%$ \\
$\quad$ Multigravida & & \\
Gestational age & 5 & $58.4 \%$ \\
$<37$ weeks & 7 & \\
$>37$ weeks & & \\
\hline
\end{tabular}

Table 3 Distribution of Body Mass Index in Preeclampsia and Eclampsia

\begin{tabular}{lcc}
\hline Characteristic & Total & Percentage \\
\hline Preeclampsia $(\mathbf{n}=\mathbf{1 2 8})$ & & \\
Normal & 32 & $32.8 \%$ \\
Overweight & 61 & $47.7 \%$ \\
Obese & 25 & $19.5 \%$ \\
Eclampsia $(\mathbf{n}=\mathbf{1 2})$ & & \\
Normal & 4 & $33.4 \%$ \\
Overweight & 6 & $50 \%$ \\
Obese & 2 & $16.6 \%$ \\
\hline
\end{tabular}

Table 4 Distribution of Nutritional Status in Preeclampsia and Eclampsia

\begin{tabular}{lcc}
\hline Characteristic & Total & Percentage \\
\hline Preeclampsia $(\mathbf{n}=\mathbf{1 2 8})$ & & \\
Normal & 17 & $13.3 \%$ \\
Undernourished & 18 & $14.1 \%$ \\
Overnourished & 93 & $72.6 \%$ \\
Eclampsia $(\mathbf{n}=\mathbf{1 2})$ & & \\
Normal & 2 & $16.6 \%$ \\
Overnourished & 10 & $83.4 \%$ \\
\hline
\end{tabular}

As shown in table 3 , it shows preeclampsia patients with normal BMI has 42 persons, BMI with overweight has 61 persons, and the number of BMI with obese is 25 persons. From the data, the number of patients with preeclampsia is higher in overweight compared to normal and obese. Also, among the 12 persons of eclampsia patients, half of the eclampsia patients which is 6 persons are overweight. Eclampsia patients with normal BMI have 4 cases and BMI with obese only 2 cases.

As shown in table 4, preeclampsia patients with undernourished have 18 persons, normal nutritional has 61 persons, and overnourished has 93 persons. It seems that overnourished preeclampsia patients are the most. Overnourished eclampsia patients are highest compared to the normal nutritional status which are 10 cases and 2 cases respectively.

As shown in table 5, it seems that the highest number of preeclampsia patients is without risk factors which are 96 persons, followed by history of preeclampsia which is 13 persons, chronic hypertension in 11 persons, diabetes mellitus and multiple pregnancies only has 3 persons respectively and the least is age $>40$ years old which only 2 persons. In risk factors of eclampsia patients, history of preeclampsia and chronic hypertension is lowest which are 1 case for each category and 10 cases in eclampsia patients without risk factors.

Table 6 shows that preeclampsia patients with low socioeconomic status have 26 persons. Preeclampsia patients with high socioeconomic status have 16 persons. However, the number of preeclampsia patients with middle socioeconomic status is the highest which is 86 persons. The number of the low socioeconomic status of eclampsia patients is 6 cases; middle socioeconomic status is 4 cases and only 2 cases of eclampsia patients with high socioeconomic status.

\section{DISCUSSION}

\section{Expecting Age}

Based on expecting age of pregnant mother, 20-35 years old has the highest number of cases in preeclampsia and eclampsia which are 86 persons and 10 persons respectively. A preeclampsia and eclampsia study conducted by Palupi \& Indawati (2014) in East Jawa by using 373 cases found that the highest expecting age group is 20-35 years old. Another study conducted by Djannah \& Arianti (2010) in PKU Muhhamdiah Yogyakarta hospital shows that expecting age group of 20-35 years old is the highest in 118 preeclampsia and eclampsia cases. ${ }^{3}$ In addition, a case-control study conducted by Astuti (2015) by using 40 preeclampsia cases also shows 20-35 years old is the highest which hold $55 \%$ of the cases. ${ }^{12}$ Another study by Thornton et al. (2008) on the incidence of preeclampsia and eclampsia and associated maternal mortality in Australia by using 22,298 preeclampsia patients and 529 eclampsia patients, it found that the average age 
Table 5 Distribution of Risk Factors in Preeclampsia and Eclampsia

\begin{tabular}{lcc}
\hline Characteristic & Total & Percentage \\
\hline Preeclampsia $(\mathbf{n}=\mathbf{1 2 8})$ & & \\
Without risk factors & 96 & $75 \%$ \\
Diabetes Mellitus & 3 & $2.3 \%$ \\
Chronic hypertension & 11 & $8.6 \%$ \\
Multiple pregnancy & 3 & $2.3 \%$ \\
Age $>40$ years old & 2 & $1.6 \%$ \\
History of preeclampsia & 13 & $10.2 \%$ \\
Eclampsia (n = 12) & 10 & \\
Without risk factors & 1 & $83.4 \%$ \\
History of preeclampsia & 1 & $8.3 \%$ \\
Chronic hypertension & & $8.3 \%$ \\
\hline
\end{tabular}

Table 6 Distribution of Socioeconomic Status in Preeclampsia and Eclampsia

\begin{tabular}{lcc}
\hline Characteristic & Total & Percentage \\
\hline Preeclampsia $(\mathbf{n}=\mathbf{1 2 8})$ & & \\
$\quad$ Low & 26 & $20.3 \%$ \\
Middle & 86 & $67.2 \%$ \\
High & 16 & $12.5 \%$ \\
Eclampsia $(\mathbf{n}=\mathbf{1 2})$ & & \\
Low & 6 & $50 \%$ \\
Middle & 4 & $33.4 \%$ \\
High & 2 & $16.6 \%$ \\
\hline
\end{tabular}

of preeclampsia is 29.5 years old. This report is similar to researcher's finding. ${ }^{13}$ Furthermore, a study by Poonyth et al. (2003)the maternal mortality rate (MMR about the epidemiology of preeclampsia in Mauritius Island with 862 subjects, it found that incidence of preeclampsia increases from the expecting age of 25-29 years old and reach the peak at the age of 30-34 years old. This finding is different from researcher's report. ${ }^{14}$

According to the epidemiology review of preeclampsia conducted by Trogstad et al. (2011), it mentions that extreme maternal age is the risk factor for preeclampsia and women who are 40 years old has 2 times the risk of getting preeclampsia compared to women who are younger. However, younger age does not have any relationship in increasing the risk of getting preeclampsia. The risk of getting preeclampsia reaches $30 \%$ when women get pregnant from the age of 34 years old and above. In this study, it is found that preeclampsia and eclampsia occur in the productive age of 20-35 years old. It is likely affected by the number of pregnant women to emergency unit which normally is the age group of 20-35 years old and holds $71 \%$ which may influence the statistic results in expecting age group..$^{15}$
From the attached table 7, research's also found that age-specific rate for expecting mother $<20$ years old is higher than 20-35 years old may due to mother $<20$ years old is getting their first marriage and first time pregnancy which can be considered as primigravida (the product of contraception from man's sperm and woman's ovum). Immunology intolerance theory can explain it. In normal women, their body will not reject the product of contraception because of HLA-G. However, in preeclampsia women, the level of HLA-G has been lowered and the zygote considered as a foreign body. This disrupts the invasion of trophoblast into the decidua and disturbs the dilation from spiral artery which leads to high blood pressure and results in preeclampsia. ${ }^{16}$

Last but not least, the age-specific rate for $>35$ years old is the highest which can be caused by several factors such as older age, history of preeclampsia and chronic hypertension. Foreign and women age $>35$ years old, they might have chronic hypertension which the muscle layers near spiral artery will stiffen and lumen spinal artery also vasoconstriction. It can lead to failure of spiral artery remodeling. Blood flow to uteroplacental will decrease and lead to hypoxia and placental ischemia. ${ }^{17}$

\section{Gravida and Gestational Age}

From the data collected in this research, we found that the proportion of primigravida that experience preeclampsia and eclampsia is higher compared to secundigravida and multigravida which is $39.4 \%$ cases. A study by Indriani (2012) regarding the analysis of risk factors for preeclampsia patients in Kardinah hospital involving 80 subjects found that proportion of preeclampsia patient from 20-35 years old with the proportion of 53\%, and it also exposes proportion of gestation age of $>37$ weeks with the proportion of $66.8 \%$. Both of these findings are the same obtained by the researcher. ${ }^{18}$ Another study by Djannah \& Arianti (2010) on preeclampsia and eclampsia patients at PKU Muhhamdiah Yogyakarta hospital involving 118 cases found that the proportion of primigravida is dominant which is $69.5 \%$ and it has the same finding with researcher. ${ }^{3}$ Furthermore, a study conducted by Wuryandari (2012) about the relationship of factors with preeclampsia incidents in Ratte Mattaher Jambi hospital by using 886 cases, the proportion of primigravida in preeclampsia patients is more dominant which is $47 \%$ and there is a correlation between primigravida and preeclampsia with $\mathrm{p}$ value $=0.000 .^{19}$ A study conducted by Boghossian et al. (2014) on risk factors differ between reccurent and incident preeclampsia by using 26613 subjects, it found 
that 1137 subjects experienced preeclampsia in their first pregnancy with proportion of $5 \%$. Later on, 341 subjects experienced preeclampsia in their second pregnancy and have a proportion of $1.2 \%$ while 155 subjects experiences recurrent preeclampsia with a proportion of $0.05 \%$. This finding is the same with researcher. ${ }^{20}$

Primigravida has a higher risk of experiencing preeclampsia which can be explained by an angiogenic factor. During primigravida, the level of sF1T-1 is higher compared to multipara which sF1T-1 is an inhibitor of the placenta and vascular endothelial growth factor which produces from endothelial dysfunction. High level of sF1T-1 will disrupt the placenta and causes hypertension and lead to preeclampsia. ${ }^{21}$

\section{Body Mass Index and Nutritional Status}

Based on the BMI results, it shows that eclampsia and preeclampsia patients are greater in overweight category with the proportion of $50 \%$ and $47.6 \%$ respectively. Research by Warouw, Suparman \& Wagey (2016) on a characteristic of preeclampsia patients in Kandou Manado hospital by using 210 cases, it found that preeclampsia patients are dominant in overweight and obese BMI category with the proportion of $31.6 \%$ and $46.6 \%$ respectively. ${ }^{22}$ This finding is almost the same with the researcher. Another research carried out by Andriani \& Lipoeto (2013) on relationship between BMI and preeclampsia involving 46 cases shows that overweight is highest with proportion of $45 \%$ and there is a significant association between BMI and preeclampsia. ${ }^{23}$

The proportion of overnourished in nutritional status is dominant in preeclampsia and eclampsia which is $72.3 \%$ and $83.4 \%$, respectively. A study conducted by Rozikhan (2007) in Dr. Soewondo Kendal hospital by using 200 cases, it found that the proportion of overnourished cases is less than normal nutritional status. This finding is contrasting from the results obtained by the researcher. However, the results of this study found that risk of getting preeclampsia and eclampsia is increased by 1.55 times in overnourished persons. ${ }^{24}$ Another study by Bodnar et al. (2005) about the risk of preeclampsia with increasing BMI with 1179 subjects found that the incidence of preeclampsia tend to be higher in overweight and obese group compared to underweight and normal which the data are underweight (3.4\%), normal (3.5\%), overweight $(8.0 \%)$ and obese $(6.4 \%)$. This finding is almost similar to the researcher's finding. ${ }^{25}$ Furthermore, another study by Boghossian et al. (2014) found that obesity grade II/III can increase the risk of preeclampsia by 2.1 times. $^{20}$ Increase in BMI is associated with an increased risk of preeclampsia. It is related to obesity that amplifies the inflammatory response in our body and proinflammatory mediator like IL- 6 and TNF- $\alpha$ will lead to preeclampsia pregnancy. ${ }^{15}$

\section{Risk factors}

According to the results of this study, it found that most of preeclampsia and eclampsia occurs without risk factors with the proportion of $75 \%$ and $83.4 \%$. Another risk factor for preeclampsia and eclampsia is a history of preeclampsia with the proportion of $10.1 \%$ in preeclampsia cases while $8.3 \%$ in eclampsia cases. A study by Elok and Hendrati (2014) on the epidemiology of preeclampsia and eclampsia in Dr. Soewandhi Surabaya Hospital involving 70 cases shows that the proportion of without risk factors in preeclampsia and eclampsia is $74 \%$ and history of previous preeclampsia with a proportion of $18 \%$. These findings are the same with researcher. ${ }^{26}$ Furthermore, a study by Djannah and Arianti (2010) also found the same thing which the incidence of preeclampsia without risk factors has a proportion of $83 \%$ and it is almost similar to researcher's finding. ${ }^{3}$ A study conducted by Wuryandari (2012) by using 886 cases at Ratte Mattaher Jambi hospital, it also shows a similar result with researcher which the incidence of preeclampsia without risk factors has a proportion of $81.5 \% .{ }^{19}$ Last but not least, the previous history of preeclampsia tend to increase the risk of getting recurrent preeclampsia during pregnancy for 7 times. Women with recurrent preeclampsia tend to experienced severe preeclampsia. ${ }^{15}$

\section{Socioeconomic status}

The result of this research found that the majority of preeclampsia cases is middle socioeconomic status with a proportion of $67 \%$ while the majority of eclampsia cases is low socioeconomic status with a proportion of 50\%. A study by Rozikhan (2007) shows that middle socioeconomic status in preeclampsia status is higher compared to others with a proportion of $69 \%$ cases. $^{24}$ Additionally, another study conducted by Makbruri (2015) on preeclampsia is a risk factor for low birth weight baby in Palembang by using 278 cases; it found that middle socioeconomic status has a proportion of $98 \%$ in preeclampsia cases. This finding is similar to researcher. ${ }^{27}$

\section{LIMITATION}

The limitation of this research is it is conducted as a descriptive study which it only studies on risk factors and characteristic of preeclampsia and eclampsia patients and does not involve further research on the relationship between each variable. Furthermore, it is important not mention that the data collected in this study is secondary data taken 
from medical records at Sanglah hospital. Also, the data for socioeconomic status is based on educational level, occupation, address, the frequency of antenatal care and hospital fees of pregnant patients which is assumed by the researcher.

\section{CONFLICT OF INTEREST}

Researcher considers that there is no conflict of interest in this study.

\section{CONCLUSION}

In this research, the expecting age of 20-35 years old in preeclampsia and eclampsia cases is the highest. Primigravida with gestational age $>37$ weeks is the highest. Overweight is the greatest in BMI category while overnourished has the most number of cases. The majority of preeclampsia and eclampsia cases occur without risk factors. Middle socioeconomic status is dominant in socioeconomic status.

\section{REFERENCES}

1. Hutcheon, J.A., Lisonkova, S., and Joseph, K.S. Epidemiology of Pre-eclampsia and the Other Hypertensive Disorders of Pregnancy. Best Practice \& Research Clinical Obstetrics and Gynaecology 2011; 25(4): 391-403

2. Shamsi U., Saleem S., and Nishter N. Epidemiology and Risk Factors of Preeclampsia; an Overview of Observational Studies. Al Ameen J Med Sci 2013; 6(4): 292-300

3. Djannah, S.N., and Arianti, I.S. "Gambaran Epidemiologi Kejadian Preeklampsia/Eklampsia di RSU PKU Muhammadiyah Yogyakarta Tahun 2007-2009”. Buletin Penelitian Sistem Kesehatan 2010; 13(4): 378-385.

4. Sonia G., Yolanda F., and Mirani P. Angka Kejadian Persalinan Preterm pada Ibu dengan Preeklampsia Berat dan Eklampsia di RSUP Dr. Mohammad Hoesin Palembang Tahun 2013. MKS 2015; 47(1): 31-34.

5. Callahan, T.L., and Caughey, A.B. Hypertension and Pregnancy. In: Callahan T.L., Caughey A.B., eds. Blueprints in Obstetrics and Gynecology. 6th ed. Philadelphia: Lippincott Williams \& Wilkins; 2013: 111-119.

6. Wei, S., Audibert, F., Hidiroglou, N., Sarafin, K., Julien, P., Wu, Y., Luo, Z., and Fraser, W. Longitudinal Vitamin D Status in Pregnancy and The Risk of Pre-eclampsia. BJOG 2012; 119(7): 832-839.

7. Shand A., Nassar N., Von Dadelszen P., Innis S., and Green T. Maternal Vitamin D Status in Pregnancy and Adverse Pregnancy Outcomes in A Group at High Risk For Pre-eclampsia. BJOG 2010;117(13): 1593-1598.

8. Powe, C.E., Seely, E.W., Rana, S., Bhan, I., Ecker, J., Karumanchi, S.A., and Thadhani, R. First Trimester Vitamin D, Vitamin D Binding Protein, and Subsequent Preeclampsia. Hypertension 2010; 56(4): 758-763.

9. Ahmadi, S.A.Y., Shahsavar, F., and Hasanvand, A. Controversies on Preeclampsia through the lens of Reproductive Immunology: A Systematic Review. Int J Integr Med Sci 2016; 3(2): 225-228.

10. Rossi, A.C., and Mullin, P.M. Prevention of Pre-eclampsia With Low-dose Aspirin or Vitamins C and E in Women at High or Low Risk: A Systematic Review With MetaAnalysis. Eur J Obstet Gynecol Reprod Biol 2011; 158(1): 9-16.
11. Bujold, E. et al. Prevention of Preeclampsia and Intrauterine Growth Restriction With Aspirin Started in Early Pregnancy. Obstet Gynecol 2010; 116(2, Part 1): 402-414

12. Astuti S.F. Faktor-Faktor Yang Berhubungan Dengan Kejadian Preeklampsia Kehamilan di Wilayah Kerja Puskesmaspamulang Kota Tangerang Selatan Tahun 20142015; 2015.

13. Thornton, C., Dahlen, H., Korda, A., and Hennessy, A. The Incidence of Preeclampsia and Eclampsia and associated Maternal Mortality in Australia from Population-Linked Datasets: 2000-2008. Am J Obstet Gynecol 2013; 208(6): 476.e1-5.

14. Poonyth, L., Sobhee, R., and Soomaree, R. Epidemiology of Preeclampsia in Mauritius Island. Journal of Reproductive Immunology 2003; 59: 101-109.

15. Trogstad, L., Magnus, P., and Stoltenberg, C. Pre-eclampsia: Risk factors and Causal Models. Best Practice \& Research Clinical Obstetrics and Gynaecology 2011; 25(3): 329-342.

16. Angsar M.D. Hipertensi Dalam Kehamilan. In: Saifuddin A.B., Rachimhadhi T., Wiknjosastro G.H., eds. Ilmu Kebidanan Sarwono Prawirohardjo. Jakarta: Pt Bina Pustaka Sarwono Prawirohardjo; 2016: 530-561.

17. Sánchez-Aranguren L.C., Prada C.E., Riaño-Medina C.E., and Lopez M. Endothelial Dysfunction and Preeclampsia: Role of Oxidative Stress. Front Physiol 2014; 5:372.

18. Indriani, N. Analisis Faktor-faktor yang Berhubungan dengan Preklampsia/Eklampsia pada Ibu Bersalin di Rumah Sakit Umum Daerah Kardinal Kota Tegal Tahun 2011; 2012.

19. Wuryandari, A.G. Faktor-faktor Yang Berhubungan Dengan Kejadian Pre-Eklampsia Di RSUD Raden Mattaher Jambi Tahun 2012. Jurnal Penelitian Universitas Jambi Seri Sains 2012; 15(1): 17-26.

20. Boghossian, N.S., Yeung, E., Mendola, P., Hinkle, S.N., Laughon, S.K., Zhang, C., and Albert, P.S. Risk Factors Differ between Recurrent and Incident Preeclampsia: A Hospital-based Cohort Study. Annals of Epidemiology 2014; 24(12): 871-7e3

21. Maynard, S.E., and Karumanchi, S.A., Angiogenic Factors and Preeclampsia. Semin Nephrol 2011; 31(1): 33-46.

22. Warouw P.C., Suparman E., and Wagey F.W. Karakteristik Preeklampsia di RSUP Prof. Dr. R. D. Kandou Manado. Jurnal e-Clinic 2016; 4(1): 375-379

23. Andriani, C., Lipoeto, N.I., and Utama, B.I. Hubungan Indeks Massa Tubuh dengan Kejadian Preeklampsia di RSUP Dr. M. Djamil Padang. Jurnal Kesehatan Andalas 2013; 5: 173-178.

24. Rozikhan. Faktor Faktor Risiko Terjadinya Preeklampsia Berat Di Rumah Sakit Dr. H. Soewondo Kendal. Undip E-Journal System Portal; 2007.

25. Roberts, J.M., Bodnar, L.M., Patrick, T.E., and Powers, R.W. The Role of Obesity in Preeclampsia. Pregnancy Hypertens. Pregnancy Hypertension: An International Journal of Women's Cardiovascular Health 2011; 1(1): 6-16.

26. Elok, F., and Hendrati, L.Y. Hubungan Karakteristik Ibu, ANC dan Kepatuhan Perawatan Ibu Hamil dengan Terjadinya Preeklampsia. Jurnal Berkala Epidemiologi 2014; 2(2): 216-226.

27. Makbruri. Faktor Risiko yang Memengaruhi Berat Badan Lahir Rendah dan Sangat Rendah di Kecamatan Seberang Ulu II Kota Palembang Periode 1 Januari-31 Desember 2008. Jurnal Gradien 2015; 11(1): 1079-1084.

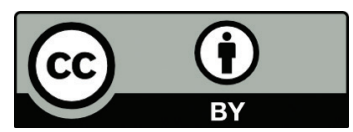

This work is licensed under a Creative Commons Attribution 